\title{
ANALISIS KEINTEGRASIAN MUATAN PELAJARAN SEKOLAH DASARKELAS II TEMA KEBERSAMAAN DALAM IMPLEMENTASI KURIKULUM 2013
}

\author{
I.K.A. Darmawan ${ }^{1}$, N. Dantes ${ }^{2}$, A.A.I.N. Marhaeni ${ }^{3}$ \\ ${ }^{123}$ Program Studi Pendidikan Dasar \\ Universitas Pendidikan Ganesha \\ Singaraja, Indonesia \\ e-mail: darmawanaria45@gmail.com ${ }^{1}$, dantes@undiksha.ac.id ${ }^{2}$, \\ ngr.marhaeni@undiksha.ac.id ${ }^{3}$
}

\begin{abstract}
Abstrak
Penelitian ini bertujuan untuk mengetahui dan mendeskrepsikan keintegrasian materi pembelajaran, rancangan langkah-langkah kegiatan pembelajaran, rancangan penilaian, serta rancangan media dan sumber belajar di buku guru dan buku siswa sekolah dasar kelas II tema kebersamaan. Penelitian ini memggunakan deskriptif kualitatif. Teknik pengumpulan data menggunakan metode dokumentasi. Analisis data yang digunakan yaitu pengumpulan data, reduksi data, penyajian data, dan penarikan kesimpulan. Berdasarkan analisis data, diperoleh hasil penelitian yaitu: 1) terdapatkeintegrasian pada materi pembelajaran dengan tingkat keintegrasian sangat baik sebesar 93,0\% dengan kasifikasi intradisipliner; 2) terdapat keintegrasian pada rancangan langkah-langkah kegiatan pembelajaran dengan tingkat keintegrasian baik sebesar $81,0 \%$ dengan kasilfikasi intradisipliner; 3) terdapat keintegrasian pada rancangan penilaian dengan tingkat keintegrasian baik sebesar $78,0 \%$ dengan klasifikasi intradisipliner; 4) terdapat keintegrasian pada rancangan media dan sumber belajar dengan tingkat keintegrasian sangat baik sebesar 90,0\% dengan klasifikasi intradisipliner dengan demikian analisi keintegrasian ini pada keempat komponen sudah baik seta dapat diimplementasikan di sekolah dasar.
\end{abstract}

Kata kunci: Keintegrasian; Kurikulum 2013; Muatan Pelajaran

\begin{abstract}
This study aims to identify and describe the integration of learning materials, the design of thesteps of learning activities, the design of assessment, as well as the design of media and learning resources in the teacher's book and the book of elementary school students in class II together themes. This research uses descriptive qualitative. Data collection techniques using the documentation method. Analysis of the data used is data collection, data reduction, data presentation, and drawing conclusions. Based on data analysis, the results of the study are as follows:1) there is integration in learning material with an excellent integration level of $93.0 \%$ with intradisciplinary verification;2) there is integration in the design of the steps of learning activities with a good integration rate of $81.0 \%$ with intradisciplinary qualifications;3) there is integration in the assessment design with good integration level of $78.0 \%$ with intradisciplinary classification;4) there is integration in media design and learning resources with a very good level of integration of $90.0 \%$ with intradisciplinary classification so that this integration analysis on the four components is good and can be implemented in primary schools.
\end{abstract}

Keywords: Integration; 2013 Curriculum; Learning Content 


\section{PENDAHULUAN}

Penerapan kurikulum 2013 yang sudah memasuki tahun ke 3 untuk revisi kedua, masih banyak guru yang belum bisa menerapkan kurikulum ini dengan baik. Workshop dan pelatihan terus diikuti guru baik lewat forum forum KKG dan yang lainnya. Penguasaan informasi teknologi (IT) merupakan salah satu dari sekian tantangan guru dalam melaksanakan kurikulum ini. Disamping itu kemampuan dan kemauan guru untuk menganalisis materi pembelajaran masih sangat rendah ditambah waktu yang tersedia dan tugas-tugas lain yang dibebankan kepada guru sangatlah banyak. Tantangan yang dihadapi guru sangat banyak sehingga kesiapan guru dalam menerapkan kurikulum ini masih sangat kurang. Analisis yang dilakukan guru baru sebatas kemunculan kompetensi dasar dan indikator. Sementara analisis yang lebih mendalam yang berkaitan prinsisp dasar dari kurikulum ini jadi terabaikan. Jika hal ini dibiarkan maka penerapan kurikulum 2013 tidak akan pernah menunjukkan hasil yang memuaskan dan ini akan berdampak pada potret pendidikan Indonesia.

Terdapat delapan karakteristik Kurikulum 2013 yaitu: (1). Isi atau kontennya dinyatakan dalam bentuk Kompetensi Inti (KI) satuan pendidikan dan kelas, dirinci lebih lanjut dalam Kompetensi Dasar (KD) mata pelajaran. (2). Kompetensi Inti (KI) merupakan gambaran secara kategorial mengenai kompetensi dalam aspek sikap, pengetahuan, dan keterampilan yang harus dipelajari peserta didik untuk suatu jenjang. (3). Kompetensi Dasar (KD) merupakan kompetensi yang dipelajari peserta didik untuk suatu tema untuk $\mathrm{SD} / \mathrm{MI}$, dan untuk mata pelajaran di kelas tertentu. (4). Kompetensi Inti dan Kompetensi Dasar dijenjang pendidikan menengah diutamakan pada ranah sikap sedangkan pada jenjang pendidikan menengah berimbang antara sikap dan kemampuan intelektual. (5). Kompetensi Inti menjadi unsur organisatoris, Kompetensi Dasar yaitu semua KD dan proses pembelajaran dikembangkan untuk mencapai kompetensi dalam Kompetensi Inti. (6). Kompetensi Dasar yang dikembangkan didasarkan pada prinsip akumulatif saling memperkuat (reinforced) dan memperkaya (enriched) antar mata pelajaran dan jenjang pendidikan (organisasi horizontal dan vertikal) diikat oleh kompetensi inti. (7). Silabus dikembangkan sebagai rancangan belajar untuk satu tema (SD). Dalam silabus tercantum seluruh KD untuk tema atau mata pelajaran di kelas tersebut. (8). Rencana Pelaksanaan Pembelajaran dikembangkan dari setiap KD yang untuk mata pelajaran dan kelas tersebut.

Pembelajaran tematik adalah model pembelajaran yang memadukan sistem pembelajaran yang memberikan kesempatan kepada siswa baik individu maupun kelompok mengembangkan potensinya dalam menggali dan menemukan konsep dan .prinsip-prinsip keilmuan secara efektif, autentik dan bermakna. Pengintegrasian materi, kegiatan pembelajaran, media/ sumber belajar dan penilaian intra dan antar muatan pelajaran merupakan pembelajaran tematik yang integratif. Integrasi tidak hanya pada materi tetapi juga pada kegiatan pembelajaran, sumber dan media pembelajaran serta pada penilaian. Dengan pembelajaran tematik integratif memberikan pengetahuan yang saling mendukung, utuh, menyeluruh, dan berkesinambungan untuk siswa. Penerapan penilaian otentik juga menghasilkan penilaian terhadap ketercapaian indikator secara nyata dan obyektif.

Trianto, (dalam Murfiah, 2017) berpendapat bahwa melalui pembelajaran terpadu ini beberapa konsep yang relevan untuk dijadikan tema tidak perlu dibahas berulang kali dalam bidang kajian yang berbeda, sehingga penggunaan waktu untuk pembahasannya lebih efisien dan pencapaian tujuan pembelajaran juga diharapkan akan lebih efektif. Sedangkan Murfiah (2017) mengatakan bahwa Pembelajaran terpadu sangat sederhana jika diterapkan dalam sekolah dasar/madrasah ibtidaiyah (SD/MI), dalam materi yang dikembangkan atau mata pelajaran yang dikembangkan memerlukan pendekatan yang terpadu sebagai acuan dasar untuk membentuk sebuah tema, pada sekolah 
dasar/madrasah

ibtidaiyah

memungkinkannya dengan pendekatan tematik tersebut. Bahkan, kompetensi inti kelas I menyeimbangkan kompetensi sikap, keterampilan dan pengetahuan. Standar kompetensi lulusan pada ranah sikap pribadi yang beriman, berakhlak mulia, percaya diri, dan bertanggung jawab dalam berinteraksi efektif dengan lingkungan sosial, alam sekitar serta dunia dan peradabannya dengan cara menerima, menjalankan, menghargai, menghayati dan mengamalkan. Standar kompetensi lulusan ranah keterampilan memiliki pribadi yang berkemampuan pikir dan tindak yang efektif dan kreatif dalam ranah abstrak dan konkret dengan caramengamati, menanya, mencoba, mengolah, menyaji, menalar dan mencipta.

Menurut Fogarty (dalam Trisdiono, 1991) terdapat sepuluh model kurikulum terpadu (integrated curriculum) dimulai dari eksplorasi dengan mata pelajaran tunggal (within single disciplines) yaitu, 1) model fragmented model ini merupakan model penggalan, yaitu memandang kurikulum dalam penggalan-penggalan mata pelajaran terpisah. Tipikalnya kurikulum terbagi dalam pelajaran utama yaitu matematika, sains, bahasa, dan ilmu sosial. Pendekatan fragmented dilakukan untuk memadukan konsep-konsep dan kompetensi dalam satu mata pelajaran. Antar kompetensi dipelajari secara bersamaan. Kompetensi mendengar, membaca, dan menulis dalam pelajaran bahasa dilakukan secara bersamaan, 2) model connected (terhubung) memandang mata pelajaran dengan menggunakan kaca pembesar (opera glass, kaca pembesar yang dipakai oleh penonton opera yang hanya satu lensa), menyediakan secara detil, seluk beluk/rinci, dan interkoneksi dalam satu mata pelajaran, 3) model nested atau model sarang memandang kurikulum dari tiga dimensional kaca baca, sasaran dimensi ganda dari pembelajaran. Tujuan pembelajaran tidak hanya pada mata pelajaran semata, namun ada beberapa pemahaman dan/atau ketrampilan yang terkuasai, 4) model sequenced melihat kurikulum menggunakan kaca-mata, lensa terbagi dalam dua bagian, namun terhubung oleh sebuah bingkai atau frame. Topik atau mata pelajaran terpisah, namun dapat dihubungkan dengan sebuah bingkai konsep yang menaungi topik atau mata pelajaran tersebut, 5) model shared melihat kurikulum menggunakan binoculars, menghubungkan dua mata pelajaran secara bersama untuk melihat sebuah topik. Keterhubungan antar dua mata pelajaran diorganisasi sehingga dapat dilakukan proses pembelajaran secara bersama-sama, 6) model webbed atau jaring laba-laba melihat kurikulum menggunakan teleskop, menangkap konstelasi pembuka dari mata pelajaran, yang membentuk sebuah tema. Tema yang ditentukan menjadi langkah awal dalam melakukan pembelajaran. Indikator masing-masing kompetensi ilmu dan pengetahuan terjabarkan dari tema tersebut, 7) model treaded melihat kurikulum dengan menggunakan kaca pembesar (magnifying glass). Ide besar diperbesar melalui semua isi dengan pendekatan kurikulum-meta (metacurricular). Model ini menggabungkan ketrampilan berpikir, ketrampilan sosial, ketrampilan belajar, mengelola grafik, teknologi, dan pendekatan kecerdasan ganda (multiple intellegences), 8) model Integrated (terpadu) melihat kurikulum menggunakan kaleidoskop. Topik interdisiplin (antar mata pelajaran) ditata kembali diantara konsep yang sama/mirip dan munculnya pola dan rancangan. Melalui pendekatan antar matapelajaran, model integrated memadukan/mencampurkan empat mata pelajaran utama dengan menemukan persamaan ketrampilan, konsep, dan sikap pada keseluruhannya, 9) model immersed melihat kurikulum menggunakan mikroskop. Melalui cara masing-masing keseluruhan konten disaring dengan menggunakan lensa ketertarikan dan keahlian yang dimiliki. Dengan menggunakan model ini, pebelajar sedikit atau sama sekali tidak ada intervensi atau bantuan dari pihak luar, dan 10) model networked atau jejaring melihat kurikulum menggunakan prisma. Menciptakan dimensi dan pengarahan ganda terhadap fokus, 
dengan menggunakan berbagai cara eksplorasi dan eksplanasi.

Forgarty (dalam Prastowo Andi, 2019: 47-51) karakteristik pengintegrasian tersebut dilakukan melalui pendekatan intradisipliner, multidisipliner, interdisipliner, dan transdisipliner.

$\begin{array}{ll}\text { 1. Karakteristik } & \text { Pendekatan } \\ \text { Intradisipliner. } & \\ \text { Karakteristik } & \text { pendekatan }\end{array}$ intradisipliner setidak-tidakanya ada empat jenis sbagai berikut: 1) pengetahuan dan keterampilan terhubung dalam satu bidang studi/keilmuan; 2) pengetahuan dan keterampilan yang dipelajari melalui mata pelajaran masing-masing; 3) sifat khas dari pembelajaran dakui dalam setiap pembelajaran; 4) kebermaknaan personal dan sosial siswa ditingkatkan dengan integrasi kognitif,afektif, dan sosial domain dengan pengetahuan dan keterampilan bidang studi.

2. Karakteristik

Pendekatan

Multidisipliner.

Karakteristik

pendekatan

multidisipliner mencakup sekurangkurangnya enam jenis sebagai berikut: 1) topik, tema, isu, atau ide besar mempertemukan hasil lebih dari bidang studi; 2) hasil tiap bidang studi tetap berbeda; 3)pengetahuan dan keterampilan yang dipelajari melalui masing-masing bidang studi pada waktu yang bersamaan terhubung ke topik lintas-kurikuler, tema, isu atau ide besar; 4) sifat khas dari pembelajaran diakui dalam setiap mata pelajaran; 5) kebermaknaan personal dan sosial siswa ditingkatkan dengan integrasi kognitif, afektif, dn sosial domain dengan pengetahuan dan keterampilan bidang studi; 6) siswa dipandu untuk melihat hubungan antara bidang studi.

3. Karakteristik Pendekatan Interdisipliner/antardisipliner.

Karakteristik

pendekatan interdispliner mencakup sekuarangkurangnya lima hal sebagai berikut: 1) topik, tema ,isu, atau ide-ide besar yang digunakan berdasarkan pada hasil yang saling terkait antara pengetahuan dan keterampilan lebih dari satu bidang studi; 2) hal-hal yang sama dan dipelajari pada mata pelajaran sudah terintegrasi dan teridentifikasi; 3) saling ketergantungan atau kesamaan pengetahuan dan keterampilan pada bidang studi yang terintegrasi dalam topik lintas-kurikuler, tema, isu, atau ide-ide besar; 4) kebermaknaan personal dan sosial siswa ditingkatkan dengan integrasi kognitif, afektif, dan sosial domain dengan pengetahuan dan keterampilan bidang studi.

4. Karakteristik

Pendekatan

Transdisipliner.

Karakteristik

pendekatan mutidisipliner yakni kurikulum ditata atas dasar perhatian dabn pertanyaan para siswa. Mereka mengmbangkan life skill sebagaimana mereka menerapkan keterampilan disiplin dan antardisiplin dalam konteks kehidupan nyata. Ada dua jalur untuk melaksanakan integrasi transdisiplin ini, yaitu project based learning dab negosiasi kurikulum.

Tahapan dalam Pembelajaran Tematik Terpadu adalah sebagai berikut:(1) Menentukan tema. Tema dapat ditetapkan oleh pengambil kebijakan,guru, atau ditetapkan bersama dengan peserta didik; (2) Mengintegrasikan tema dengan kurikulum. Desain tema pembelajaran dengan cara terintegrasi harus sejalan dengan tuntutan kurikulum, dengan mengedepankan dimensi sikap, pengetahuan, dan keterampilan; (3) Mendesain rencana pembelajaran (RPP). Tahapan ini mencakup pengorganisasian sumber belajar, bahan ajar, media belajar, termasuk kegiatan ekstrakurikuler yang bertujuan untuk menunjukkan suatu tema pembelajaran terjadi dalam kehidupan nyata; dan (4) melaksanakan aktivitas pembelajaran (Kemdikbud, 2013:197).

Komponen pembelajaran terpadu ada 4 yaitu : (1) materi pembelajaran. Oemar Hamalik (2017: 139-140) menjelaskan jenis-jenis materi pembelajaran tersebut terdiridari: (1) Pengetahuan, yang meliputi fakta, konsep, prinsip dan prosedur. Pengetahuan menunjuk kepada informasi yang disimpan dalampikiran (mind) peserta didik; (2) Keterampilan, yaitu melakukan suatu jenis kegiatan tertentu.Keterampilan (skill) biasanya menunjuk kepada tindakantindakan(intelektual atau jasmaniah) dan reaksi-reaksi (gagasan, hal-hal, atauorang) yang dilakukan oleh seseorang dengan cara yang kompeten dengan 
maksud mencapai tujuan tertentu.; (3) Sikap atau nilai, yaitu berkaitan dengan sikap atau interes (minat)peserta didik mengikuti materi pembelajaran yang disajikan guru, nilai-nilaiberupa apresiasi (penghargaan) terhadap sesuatu dan penyesuaianperasaan sosial; (2) kegiatan pembelajaran. Daryanto (2014: 389) mengatakan biasanya kegiatan pelajaran mengandung unsur: (1) uraian tentang apa yangakan dipelajari, (2) diskusi dan pertukaran pikiran, (3) kegiatankegiatanyang menggunakan berbagai alat instruksional, laboratorium, dan lainlain,(4) kegiatan-kegiatan dalam lingkungan sekitar sekolah, seperti kunjungan,kerja lapangan, eksplorasi, dan penelitian, (5) kegiatan-kegiatan denganberbagai sumber seperti, buku perpustakaan, alat audio visual, dan lainlain,(6) kegiatan kreatif seperti, drama, seni rupa, musik, pekerjaan tangan dansebagainya; (3) penilaian/evaluasi. Evaluasi diartikan sebagai suatu proses menentukan nilai sesuatuatau seseorang dengan menggunakan patokan-patokan tertentu untukmencapai tujuan (Evelin Siregar \& Hartini Nara, 2013: 142); dan (4) media/susmber belajar. Sumber belajar juga dapat diartikan sebagai daya yang bisa dimanfaatkan guna kepentingan proses belajar mengajar, baiksecara langsung maupun secara tidak langsung, sebagian atau secara keseluruhan (Nana Sudjana \& Ahmad Rivai, 2009: 76).

Untuk kelas 1-3, kompetensi dasar muatan pelajaran ilmu pengetahuan alam (IPA) diintegrasikan ke kompetensi dasar muatan pelajaran Bahasa Indonesia dan matematika. Sedangkan, kompetensi dasar muatan pelajaran ilmu pengetahuan sosial (IPS) diintegrasikan ke kompetensi dasar muatan pelajaran Bahasa Indonesia, pendidikan Pancasila dan Kewarganegaraan. Untuk kelas 4-6, kompetensi dasar kedua muatan pelajaran ini berdiri sendiri, sehingga pendekatan integrasinya adalah multidisipliner, walaupun pembelajarannya tetap menggunakan tematik integratif.

Berdasarkan pengalaman empiris peneliti ada beberapa kekurangan yang terdapat pada buku guru dan buku siswa yaitu : (1) Materi pada buku guru masih kurang lengkap sehingga harus dikembangkan lagi oleh guru dengan menggunakan buku pendamping; (2) penilaian yang dirancang pada buku guru masih belum terlihat jelas keterpaduannya utamanya pada antar muatan pelajaran. Kedua hal tersebut terjadi kesulitan memuat materi yang luas yang dapat mengakomodasi semua indikator yang muncul baik di materi maupun pada penilaian.

Maka analisis terhadap kurikulum 2013 baik dari materi pembelajaran, kegiatan pembelajaran, penilaian serta media dan sumber belajar di buku guru dan buku siswa harus dilakukan secara mendalam sehingga kateristik dari kurikulum ini dapat diketahui dan dipahami oleh guru. Dalam penelitian ini akan dilaksanakan analisis terhadap keterintegrasian muatan pelajaran sekolah dasar kelas II tema kebersamaan.

\section{METODE}

Penelitian ini memggunakan deskriptif kualitatif(Moleong, J. Lexi. 2007: 4). Teknik pengumpulan data menggunakan metode dokumentasi. Analisis data yang digunakan yaitu pengumpulan data, reduksi data, penyajian data, dan penarikan kesimpulan.Penelitian ini berfungsi untuk mengetahui dan mendeskripsikan keintegrasian muatan pelajaran pada komponen pembelajarandi sekolah dasar kelas II tema kebersamaan Kurikulum 2013.

Data penelitian ini yakni data yang berhubungan dengan keintegrasian muatan pelajaran sekolah dasar kelas II tema kebersamaan Kurikulum 2013 baik data di buku guru dan buku siswa. Sumber data dalam penelitian ini adalah buku guru dan buku siswa kelas II tema kebersamaan Kurikulum 2013. Data dan sumber data penelitian diperoleh melalui metode pengumpulan data yakni dokumentasi.

\section{HASIL DAN PEMBAHASAN Hasil}

Tabel 1. Rekapitulasi Hasil Analisis

Keintegrasian Muatan Pelajaran Pada Empat KomponenPembelajaran

Komponen Klarifikasi (\%)




\begin{tabular}{lllll}
\hline \multirow{2}{*}{ Pembelajaran } & \multicolumn{4}{l}{ Keintegrasian } \\
\cline { 2 - 4 } & TTK & II & IM & \\
\hline MP & 4 & 50 & 1 & 93,0 \\
RLLKP & 22 & 88 & 4 & 81,0 \\
RP & 19 & 68 & 1 & 78,0 \\
RMSB & 5 & 44 & 2 & 90,0 \\
Total & 50 & 250 & 8 & 84,0 \\
\hline
\end{tabular}

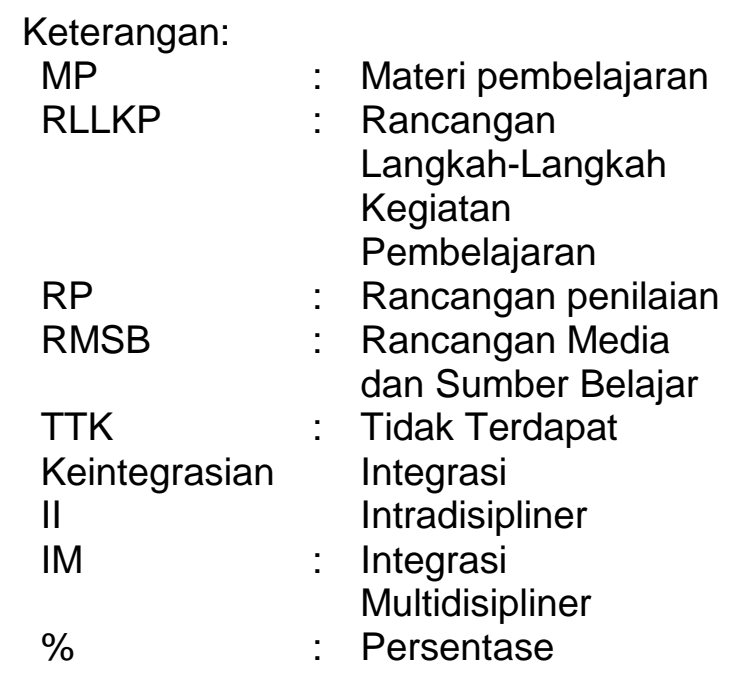

Berdasarkan Tabel 1 hasil analisis keintegrasian muatan pelajaran pada 4 komponen pembalajaran di atas dapat disimpulkan bahwa terdapat keintegrasian yang ditemukan pada materi pembelajaran (RP), rancangan langkah-langkah kegiatan pembelajaran (RLLKP), rancangan penilaian (RP), rancangan media dan sumber belajar (RMSB). Klasifikasi keintegrasian pada 4 komponen pembelajaran yaitu pertama, komponen materi pembelajaran (MP) ditemukan 4 yang tidak terdapat keintegrasian, 50 keintegrasian secara intradisipliner dan 1 keintegrasian secara multidisipliner. Sehingga dapat disimpulkan kecenderungan keintegrasian pada komponen materi pembelajaran (MP) yaitu integrasi intradisipliner dengan tingkat keintegrasian sangat tinggi. Kedua,komponen rancangan langkahlangkah kegiatan pembelajaran (RLLKP) ditemukan 22 yang tidak terdapat keintegrasian, 88 keintegrasian secara intradisipliner dan 4 keintegrasian secara multidisipliner. Sehingga dapat disimpulkan kecenderungan keintegrasian pada komponen rancangan langkahlangkah kegiatan pembelajaran (RLLKP) yaitu integrasi intradisipliner dengan tingkat keintegrasian baik.
Ketiga,komponen rancangan penilaian (RP) ditemukan 19 yang tidak terdapat keintegrasian, 68 keintegrasian secara intradisipliner, dan keintegrasian secara multidisipliner sebanyak 1 . Sehingga dapat disimpulkan kecenderungan keintegrasian pada komponen rancangan penilaian (RP) yaitu integrasi intradisipliner dengan tingkat keintegrasian baik. Keempat,komponen rancangan media dan sumber belajar (RMSB) ditemukan 2 yang tidak terdapat keintegrasian, 44 keintegrasian secara intradisipliner dan ditemukan 2 keintegrasian secara multidisipliner. Sehingga dapat disimpulkan kecenderungan keintegrasian pada komponen rancangan media dan sumber belajar (RMSB) yaitu integrasi intradisipliner dengan tingkat keintegrasian sangat tinggi.

Berdasarkan pemaparan hasil analisis keintegrasian muatan pelajaran pada 4 komponen pembalajaran ditemukan 50 yang tidak terdapat keintegrasian, 250 keintegrasian secara intradisipliner dan ditemukan 8 keintegrasian secara multidisipliner. Sehingga dapat disimpulkan kecenderungan keintegrasian muatan pelajaran pada 4 komponen pembelajaran di buku guru danbukusiswasekolahdasarkelas II tema Kebersamaan secara keseluruhan yaitu integrasi intradisipliner (250 keintegrasian) dengan tingkat keintegrasian sangat tinggi.

\section{Pembahasan \\ Pembahasan Rumusan Masalah
Pertama}

Hasil analisis pertama menunjukkan terdapat keintegrasian muatan pelajaran pada materi pembelajaran. Hasil penelitian menunjukkan bahwa terdapat keintegrasian pada materi pembelajaran sekolah dasar kelas II tema Kebersamaan yaitu integrasi intradisipliner dengan persentase keintegrasian sebesar 93\% berkatagori sangat baik.

Pada materi pembelajaran sekolah dasar kelas II tema Kebersamaan, keintegrasian yang terjadi lebih banyak pada keintegrasian secara intradisipliner. Keintegrasian secara intra disipliner adalah keintegrasian yang terjadi dalam 
satu muatan pelajaran tetapi dapat memfasilitasi pencapaian lebih dari satu tujuan pembelajaran. Sebagian besar materi pembelajaran yang disajikan hanya mampu memfasilitasi tujuan-tujuan pembelajaran dalam satu muatan pelajaran saja. Dalam satu pembelajaran yang memfokuskan pada 3 muatan pelajaran, masing-masing muatan pelajaran disajikan materi tersendiri, meskipun dari materi pembelajaran tersebut dapat memfasilitasi pencapaian lebih dari satu tujuan pembelajaran.

Hal ini kemungkinan disebabkan karakteristik tema, subtema, kompentensi inti, dan kompetensi dasar tidak memungkinkan menyusun materi pembelajaran yang terintegrasi yang dapat memfasilitasi pencapain lebih dari satu tujuan pembelajaran dan lebih dari satu muatan pelajaran. Kemendikbud (2013: 192-193) menjelaskan bahwa,

Pembelajaran tematik terpadu/tematik integratif menggunakan tema sebagai pemersatu kegiatan pembelajaran yang memadukan beberapa mata pelajaran sekaligus dalam satu kali tatap muka, sehingga peserta didik dapat memperoleh pengalaman belajar yang lebih bermakna, karena peserta didik selalu melalui pengalaman langsung dalam memahami berbagai konsep yang mereka pelajari kemudian menghubungkannya dengan konsep lain yang telah mereka kuasai.

Hal ini didukung oleh venville (dalam Harli Trisdiono, 2009:4) bahwa beberapa hambatan dalam penerapan kurikulum tematik integratif ada faktor guru yaitu pengetahuan dan kualifikasi materi pelajaran/subject matter, pengetahuanisi pedagogigal, kepercayaan tentang dan pengalaman sekolah, sebagaimana praktik pembelajaran selama ini; dan faktor kontekstual yaitu kebijakan administratif, panduan kurikulum, proses penilaian dan pelaporan, dan tradisi sekolah.

Buku kelas II tema Kebersamaan
sudah bisa dikatakan buku yang
terintegrasi dalam aspek materi
pembelajaran, keintegrasiannya masih
bersifat intradisipliner meskipun ada
sebagian kecil sudah multidisipliner.
Keintegrasian dalam setiap buku itu

berbeda-beda, hal itu sangat besar kemungkinannya dipengaruhi oleh karakteristik tema, muatan pelajaran yang menjadi fokus pembelajaran, kompetensi inti dan kompetensi dasar yang dikembangkan.

\section{Pembahasan Rumusan Masalah Kedua}

Hasil analisis kedua menunjukan terdapat keintegrasian muatan pelajaran pada rancangan langkah-langkah kegiatan pembelajaran. Hasil penelitian menunjukkan bahwa terdapat keintegrasian pada rancangan langkahlangkah kegiatan pembelajaran di buku guru dan buku siswa sekolah dasar kelas II tema Kebersamaan yaitu integrasi intradisipliner dengan persentase keintegrasian sebesar $81 \%$ berkatagori baik.

Keintegrasian yang terjadi pada buku guru dan buku siswa kelas II tem Kebersamaan pada aspek rancangan langkah-langkah kegiatan pembelajaran yaitu keintegrasian secara intradisipliner. Rancangan langkah-langkah kegiatan pembelajaran atau RLLKP dikembangkan setelah menyusun dan mengembangkan materi pembelajaran. Dapat dikatakan bahwa RRLKP dikembangkan untuk mengaplikasikan materi pembelajaran kepada siswa dalam proses pembelajarannya. RLLKP sangat bergantung pada karakteristik materi pembelajaran, jika materi pembelajaran keintegrasiannya intra disipliner maka kemungkinan besar juga RLLKP nya juga memiliki keintegrasian yang intradisipliner.

Keintegrasian RLLKP secara intradisipliner dimaksudkan karena dalam kegiatan-kegiatan pembelajaran yang dirancang mampu memfasilitasi pencapaian tujuan pempelajaran lebih dari satu meskipun masih dalam satu muatan pelajaran. Pada buku guru dan buku siswa kelas II tema Kebersamaan, ditemukan dalam satu pembelajaran memfokuskan lebih dari satu muatan pelajaran tetapi dalam RLLKP masih tersendiri ke masingmasing muatan pelajaran.

Buku kelas II tema Kebersamaan sudah bisa dikatakan buku yang terintegrasi dalam aspek rancangan langkah-langkah kegiatan pembelajaran, keintegrasiannya masih bersifat 
intradisipliner meskipun ada sebagian kecil sudah multidisipliner. Keintegrasian dalam setiap buku itu berbeda-beda, hal itu sangat besar kemungkinannya dipengaruhi oleh karakteristik tema, muatan pelajaran yang menjadi fokus pembelajaran, kompetensi inti dan kompetensi dasar yang dikembangkan.

\section{Pembahasan Rumusan Masalah Ketiga}

Hasil analisis menunjukkan terdapat keintegrasian muatan pelajaran pada rancangan penilaian. Hasil analisis menunjukkan bahwa terdapat kecendrungan penilaian di buku guru dan buku siswa sekolah dasar kelas II tema Kebersamaan yaitu integrasi intradisipliner dengan persentase keintegrasian sebesar $78 \%$ berkatagori sedang.

Integrasi pada aspek penilaian di buku guru dan buku siswa sekolah dasar kelas II tema Kebersamaan terlihat dari instrumen dan rubrik penilaian yang digunakan. Pada penilaian proses yakni penilaian sikap terintegrasi pada aspek sikap yang diamati. Pada penilaian hasil yaitu aspek pengetahuan terlihat dari bentuk tes yang digunakan. Tes yang digunakan untuk ranah kognitif berbentuk tes tertulis yang menggunakan kata tanyayang bersifat menguraikan jawaban, misalnya bagaimana dan mengapa. Pada aspek keterampilan terlihat dari rubrik penilaian yang digunakan, misalnya keterampilan (a) membacakan hasil pekerjaan, (b) diskusi, dan (c) membuat produk.

Istrumen penilaian yang

dikembangkan pada buku guru dan buku siswa untuk mengukur ketercapaian dari materi pembelajaran dan rancangan langkah-langkah kegiatan pembelajaran yang dikembangkan. Analisis pada buku guru dan buku siswa menunjukkan bahwa instrumen penilaian yang ada hanya mampu memfasilitasi pengkuran ketercapaian penilaian tujuan tujuan pembelajaran pada satu muatan pelajaran saja. Hal ini sejalan dengan Kemendikbud (Panduan Teknis Penilaian di SD Kurikulum 2013, 2013: 7) yang menjelaskan bahwa penilaian autentik adalah penilaian yang dilakukan secara luas, lengkap dan menyeluruh untuk dapat menilai aspek sikap, pengetahuan dan keterampilan mulai dari masukan (input), proses, sampai pada keluaran (output) pembelajaran. Penilaian ini memiliki sifat alami, apa adanya dan tidak dalam suasana tertekan. Penilaian autentik ini tidak hanya mengukur apa yang diketahui oleh siswa, namun lebih menekankan mengukur apa yang dapat dilakukan oleh siswa.

Buku kelas II tema Kebersamaan sudah bisa dikatakan buku yang terintegrasi dalam aspek penilaian, keintegrasiannya masih bersifat intradisipliner meskipun ada sebagian kecil sudah multidisipliner. Keintegrasian dalam aspek penilaian setiap buku itu berbeda-beda, beberapa faktor yang mempengaruhi adalah karakteristik tema, muatan pelajaran yang menjadi fokus pembelajaran, kompetensi inti dan kompetensi dasar yang dikembangkan.

\section{Pembahasan Rumusan Masalah Keempat}

Hasil analisis keempat menunjukkan terdapat keintegrasian muatan pelajaran pada rancangan media dan sumber belajar. Hasil analisis menunjukkan bahwa terdapat keintegrasian pada rancangan media dan sumber belajar di buku guru dan buku siswa kelas II tema Kebersamaan yaitu integrasi intradisipliner dengan persentase keintegrasian sebesar $90 \%$ berkatagori sangat baik.

Dalam pembelajaran tematik terpadu, sumber belajar utama di buku guru dan buku siswa sekolah dasar kelas II tema Kebersamaan menggunakan bentuk teks tertulis, seperti buku, majalah, brosur, surat kabar, poster, atau berupa lingkungan sekitar seperti lingkungan alam dan lingkungan sosial sehari-hari. Hal ini sejalan dengan Piaget (dalam Prastowo, 2019: 100) yang menyatakan penggunaan sumber belajar, bahan ajar, media, dan alat peraga itu penting dan sangat relevan mengingat siswa sekolah dasar umur 711 tahun berada dalam perkembangan kemampuan intelektual pada tingkata operasional kongkret.

Jenis media yang sangat bermacammacam merupakan salah satu tantangan bagi guru untuk memilihan dan menggunakan media berkaiatan erat dengan ketersediaan dan keseuaian 
dengan materi pembelajaran yang akan ditransfer ke peserta didik. Anderson (dalam Prastowo, 2019: 108) mengungkapkan sebagai berikut

Pemilihan media yang tepat,yang dapat membantu dalam mencapai tujuan instruksional (pembelajaran) yang telah ditentukan, bukanlah tugas yang mudah. Seperti halnya dalam memilih metode ststistik, kita memerlukan bantuan sebanyak mungkin dalam memilih media yang kita perlukan itu. Sayangnya,mencari informasi yang dapat memberikan bantuan yang kita perlukan dalam memilih media, tidaklah mudah.

Sementara itu Sudjana dan Rivai (1989: 84-86) yang menyebutkan ada dua kriteria dalam memilih media dan sumber belajar yaitu kriteria umum dan kriteria khusus. Dengan hal tersebutakan memudahkan dalam, pemilihan media dan sumber belajar yang efektif dan efisien. Hendaknya media dan sumber belajar yang dipilih sesuai dengan kebutuhan dan ketentuan pada tujuan pembelajaran yang ingin dicapai.

\section{PENUTUP}

Berdasarkan hasil penelitian dan pembahasan di atas, maka peneliti menyimpulkan sebagai berikut:

1. Terdapat keintegrasian muatan pelajaran pada materi pelajaran (MP) sekolah dasar kelas II tema Kebersamaan yaitu integrasi intradisipliner (50 keintegrasian) dengan persentase keintegrasian sebesar 93,0\% berkategori sangat baik.

2. Terdapat keintegrasian muatan pelajaran pada rancangan langkahlangkah kegiatan pembelajaran (RLLKP) di buku guru dan buku siswa sekolah dasar kelas II tema Kebersamaan yaitu integrasi intradisipliner (88 keintegrasian) dengan persentase keintegrasian sebesar $81,0 \%$ berkategori baik.

3. Terdapat keintegrasian muatan pelajaran pada rancangan penilaian (RP) di buku guru dan buku siswa sekolah dasar kelas II tema Kebersamaan yaitu integrasi intradisipliner (68 keintegrasian) dengan persentase keintegrasian sebesar $78,0 \%$ berkategori baik.

4. Terdapat keintegrasian muatan pelajaran pada rancangan media dan sumber belajar (RMSB) di buku guru dan buku siswa sekolah dasar kelas II tema Kebersamaan yaitu integrasi intradisipliner (44 keintegrasian) dengan persentase keintegrasian sebesar $90,0 \%$ berkategori sangat baik.

Berdasarkan simpulan di atas, maka ada beberapa saran yang dapat digunakan untuk meningkatkan kualitas pembelajaran dalam bukuguru da buku siswa yaitu:

1. Materi pembelajaran utamanya dongeng yang hendaknya jangan terlalu panjang sehingga murid bisa membaca sendiri dan dapat memahami lebih jelas tentang kebersamaan dan tidak terpaku pada guru yang harus membacakan dongenng tersebut.

2. Sumber yang jelas dan lengkap perlu dicantumkan pada aspek materi pembelajaran.

3. Dimensi sikap sudah terimplisit dalam proses pembelajaran sebaiknya tidak dicantumkan lagi pada tujuan pembelajaran.

\section{DAFTAR RUJUKAN}

Daryanto. 2014. Pembelajaran Tematik, Terpadu, Terintegrasi (Kurikulum2013). Yogyakarta: Gava Media

Evelin Siregar \& Hartini Nara. 2013. Teori Belajar Dan Pembelajaran. Yogyakarta: Gava Media

Kurikulum 2013 Semester II SD Kelas IV. Jakarta: Kemdikbud

Kementerian Pendidikan dan Kebudayaan 2013. Kompetensi Dasar SD/MI. Versi Maret 1.

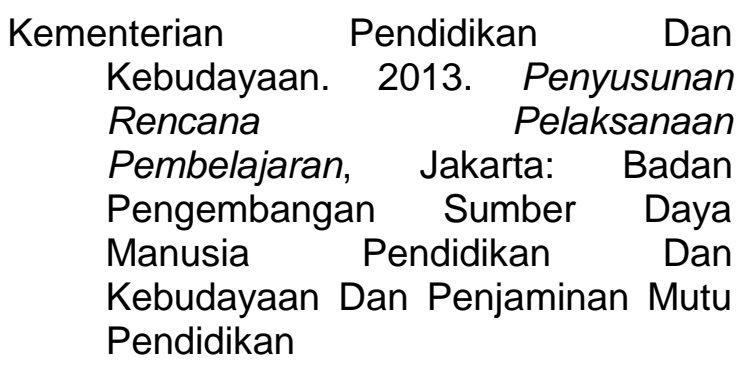


Moleong, Lexy J. 2007. Metode Penelitian Kualitatif. Bandung: PT Remaja Rosdakarya

Murfiah. 2017. Model Pembelajaran Terpadu Di Sekolah Dasar. EJournal Pendidikan Guru Sekolah Dasar (PGSD) Universitas Syiah Kuala Jurnal Pesona Dasar Vol.1 No.5. Hal: 57-69 Issn: 2337-9227 57

Nana Sudjana \& Ahmad Rivai. 1989. Teknologi Pengajaran. Bandung: Sinar Baru Algensindo

Nana Sudjana \& Ahmad Rivai. 2009. Teknologi Pembelajaran. Bandung: Sinar Baru Algensindo

Oemar, Hamalik, 2011. Kurikulum Dan Pembelajaran, Jakarta: Bumi Aksara.

Prastowo, Andi. 2019. Pengembangan Bahan Ajar Tematik. Jogjakarta: Diva Press

Trisdiono. 2013. Pembelajaran Terpadu Pada Sekolah Dasar. JournalLembaga Penjaminan. 